\title{
WANTED
}

The Association will pay $\$ 1$ each for the following back issues:

$$
\begin{aligned}
& \text { March, } 1969 \\
& \text { June, } 1969 \\
& \text { Sept., } 1969 \\
& \text { Dec., } 1969 \\
& \text { March, } 1970 \\
& \text { June, } 1970 \\
& \text { Sept., } 1970 \\
& \text { Dec., } 1970 \\
& \text { March, } 1971 \\
& \text { June, } 1971 \\
& \text { Sept., } 1971 \\
& \text { March, } 1972
\end{aligned}
$$

\section{TO SELL}

The Association has a limited number of copies of

Robert G. Layer

Earnings of Cotton Mill Operatives, 1825-1914, Harvard, 1955, 71 pp.- for sale at $\$ 1.50$

Whether you buy or sell, send your order to

H. E. Krooss

22 South 18th Street

Allentown, Pennsylvania 18104 


\section{SHIPPING, MARITIME TRADE AND \\ THE ECONOMIC DEVELOPMENT \\ OF COLONIAL NORTH AMERICA}

\section{JAMES F. SHEPHERD and GARY M. WALTON}

Using quantitative analysis, the authors of this close examination of the North American colonial economy from the mid-17th century to the Revolution place in perspective the importance of increasing market trade and regional specialization, and the pace and pattern of the economic development in general.

$\$ 14.50$

\section{MIGRATION AND ECONOMIC GROWTH}

\section{Second Edition}

\section{BRINLEY THOMAS}

The second edition of this analysis of the Atlantic economy since 1840 has six new chapters reappraising the original analysis and extending it to include Canada, Australia and Argentina. It also examines non-white immigration into Britain, the rise and fall of the transatlantic brain drain since 1950, and migration of blacks in America from 1870 to 1970.

$\$ 23.50$

\section{SOCIALIST BANKING AND MONETARY CONTROL}

The Experience of Poland

T. M. PODOLSKI

Deals with the development of financial institutions, changes in methods of finance and the role of monetary control in socialist economic management, particularly in Poland. Throughout the book comparisons are made with Soviet and western economies.

$\$ 28.50$

\section{PAPERS IN ECONOMIC PREHISTORY}

\section{Edited by E. S. HIGGS}

Papers by members and associates of the British Academy Major Research Project on the early history of agriculture, with an introduction by Grahame Clarke. The authors question current models and techniques for study of the origins of agriculture, and suggest that close man-animal and man-plant relationships are of a much earlier date and wider distribution than has been supposed.

$\$ 15.50$

\section{FARMING AND FOOD SUPPLY}

\section{Sir JOSEPH HUTCHINSON}

"A concise summary of the historical evolution of agricultural systems viewed in the light of general human advancement. Packed with facts, logical deduction and acute observation."-World Hunger

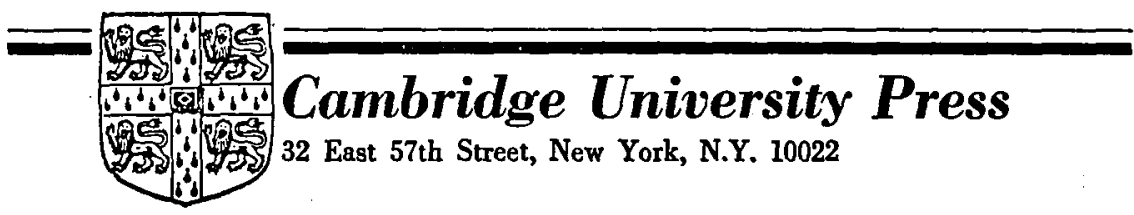




\title{
R. H. Tawney and his Times
}

\section{Socialism as Fellowship}

Ross Terrill

Economic historian, democratic socialist, educator, and British labor party activist, R. H. Tawney fertilized many worlds. This first study of his life and thought leans on unpublished materials, and interviews with more than fifty of his closest friends. Mr. Terrill, who believes in the relevance of social democracy, argues for the continuing validity of Tawney's view of socialism as fellowship.

$\$ 12.00$

\section{The Organization of Space in Developing Countries}

E. A.J. Johnson

In underdeveloped countries an unhealthy dichotomy between the enormous numbers of small villages and the very few large cities undermines the chances of sustained economic progress. E. A. J. Johnson here attacks the persistent "folklore of development" proposing that interlinked urban centers of graduated size be established. $\$ 15.00$

\section{The International Fconomy and Monetary Movements in France, 1493-1725}

\author{
Frank C. Spooner
}

Here is the first English edition of Mr. Spooner's L'Economie mondiale et les frappes monetaires en France, 1493-1680. Expanded to cover an additional forty-five years, it includes valuable observations on the structure of the French economy and the relationship between monetary movements and general economic trends. Harvard Economic Studies, 138.

$\$ 17.50$

\section{The Land Question and the Irish Economy, 1870-1903}

\section{Barbara Lewis Solow}

Mrs. Solow challenges the myth that Ireland's economic difficulties after the Great Famine were caused by the land tenure system. In fact, she argues, the Irish economy made impressive progress in the three decades following 1845. Basing her conclusions on new quantitative estimates of significant economic variables, she offers a fresh interpretation of the course of Irish economic development in the post-Famine period. Harvard Economic Studies, 139. 


\section{Dissent on Development}

\section{Studies and Debates in Development Economics}

\section{P. T. Bauer}

Planning and foreign aid are but two of the panaceas for developing countries that Mr. Bauer has rejected during his thirty years as a prominent scholar of development economics. In these closely reasoned pieces he covers the major issues in this field, supporting his views with evidence drawn from a wide range of primary sources and direct experience. . $\$ 15.00$

\section{Patents, Invention, and Economic Change}

\section{Data and Selected Essays}

\section{Jacob Schmookler}

$Z v i$ Griliches and Leonid Hurwicz, editors

The papers collected here form a valuable sequel to the late Jacob Schmookler's monograph Invention and Economic Growth (HUP 1966). Of particular interest is an important article on the growth of the American economy, and an extensive time series on patents granted by industrial classification. A foreword by Simon Kuznets pays tribute to Mr. Schmookler's life and work.

$\$ 11.50$

\section{Florentine Public Finances in the Early Renaissance, 1400-1433}

\section{Anthony Molho}

In his applications of statistical methods of history, Mr. Molho offers a new approach to the study of Florentine politics. Focusing on the governmental, judicial, and fiscal agencies of Florence, he has gathered and statistically reconstructed all the archival material on Florentine taxation, public income, and expenses. Harvard Historical Monographs, 65 . \$10.50

\section{Collected Papers}

\section{Lloyd A. Metzler}

The theories of Lloyd A. Metzler, long esteemed by economists and serious students of economics, are collected here in a series of papers, including four hitherto unpublished: The extensively documented volume has four sections: The Theory of International Trade; Money, Interest, and Prices; Business Cycles and Economic Fluctuations; and Mathematical Economics and Statistics. Harvard Economic Studies, 140. \$15.00

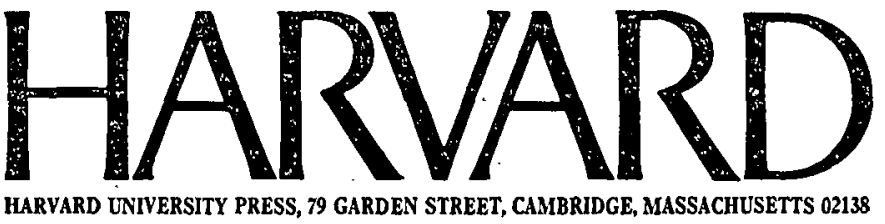




\section{Chicago}

\section{DUALISTIC ECONOMIC DEVELOPMENT}

\section{Theory and History}

\section{Allen C. Kelley, Jeffrey G. Williamson, and Russell J. Cheetham}

This innovative study provides an integrated application of formal economic theory, mathematical techniques of analysis, and economic history to the problems and issues of economic development and structural change in the low-income economy. Illustrating the presentation is an examination of Japanese economic growth during the period 1885-1915.

1972 xii, 400 pages Cloth $\$ 12.50$

\section{CHICAGO ESSAYS IN ECONOMIC DEVELOPMENT}

\section{Edited and with an Introduction by David Wall}

In this collection of essays by members of the Chicago school of economics, David Wall shows that the School's methods go a long way toward the clarification and solution of the economic problems faced by the world's underdeveloped countries. This volume rectifies misunderstandings about the Chicago school and circulates more widely some of its best work. Contributors: Theodore Schultz, Harry G. Johnson, Arnold C. Harberger, Bert F. Hoselitz, Larry A. Sjaastad, and D. Gale Johnson.

$1972 x v i, 370$ pages Cloth $\$ 14.00$

\section{The University of Chicago Press Chicago 60637}




\section{from HARPER \& ROW}

\section{AMERICAN ECONOMIC GROWTH:}

\section{An Economist's History of the United States}

Lance E. Davis, Richard A. Easterlin, William N. Parker et al.

An integrated and comprehensive study of aspects of American economic history by 12 recognized authorities in the field. Insights and arguments drawn from the authors' own quantitative research and that of others are combined with much of the standard literature on institutional and narrative history. 683 pp.; \$13.95; 1972.

\section{THE REINTERPRETATION OF AMERICAN ECONOMIC HISTORY}

\section{Edited by Robert W. Fogel and Stanley L. Engerman}

"Those historians who do not understand econometric publications are obligated to learn enough to achieve understanding. ... Certainly, THE REINTERPRETATION OF AMERICAN ECONOMIC HISTORY is as step toward the goal of enhaneed understanding. Messrs. Fogel and Engerman have brought together much of the representative output of econometric pens."-From Ralph Hidy's presidential address to the Economic History Association (1972).

494 pp.; \$12.95; 1971.

\section{THE AMERICAN LABOR MOVEMENT Edited by David Brody}

Interpretative essays by outstanding younger scholars focus on the key issues of theory and operation that have made the American labor movenent unique. The editor provides a general introduction to emphasize the historiographical background of the collection. headnotes that place each essay in the general context of the book and point to basic questons, and a bibliographic essity. 162 pp.; Paper: \$3.45; 1971.

\section{EUROPEAN ECONOMIC HISTORY: Tenth Century to the Present Elias H. Tuma}

"A precise. well-organized and well-written study which highly qualifies as a text for a general course in the economic history of Europe. ... The author's discussion effectuvely. employs analytical as well as descriptive approaches. . . Excellent chapter bibliographies.-N. A. Taqieddin, Utah State University, Intermountain Economic Re'view.

384 pp.: \$12.95: 1971.

\section{HARPER \& ROW, Publishers}

10 East 53d Street, New York 10022 


\section{$\mathbb{T H} \mathbb{E}$ \\ ECONOMIC HISTORY ASSOCIATION}

\author{
President \\ Douglass C. Nortu \\ Secretary-Treasurer \\ Herman E. Krooss
}

President Elect

Sylvia THRupr

Vice President

Robert E. Gallmax

\section{Past Presidents}

Edwin F. Gay (1940-1942)

Harold A. InNis (1942-1944)

ARthur H. COLE (1944-1946)

ANNE Bezanson (1946-1948)

Herbert Heaton (1948-1950)

Eari J. Hamilton ( 1950-1952)

EdWakd C. KirkL.ANd (1952-1954)

Carter Goodruch (1954-1956)

Frederic C. Lane: (1956-1958)

Thomas C. Cochiran (1958-1960)

E. A. I. Johnson (1960-1962)

Georie Rogers Taylor

(1962-1964)

harold F. Williamson

Alexander Gerschinkronon

(1964-1966)

(1966-1968)

Shepard B. Clough (1988-1989)

WILLIAM N. PARKER (1969-1970)

RALPH W. HIDY (1970-1971)

Al.freid D. Chandiler, Jr. (1971-1972)

\section{Board of Trustees}

VAL R. LORWIN (1968-1972)

IRENE D. NEU (1969-1973)

David S. Landes (1970-1974)

Ralph ANdReano (1971-1975)

ROBEnT IV. FOGEL (1972-1976)

\section{Honorary Members}

Fernand P. Braudec (France)

Eleanora Carus-Wilson

(United Kingdom)

Simon KuzNeTs

(United States of America)

Ernest Labrousse (France)

Michiael M. Postan

(United Kingdom)

Armando Sapori (Italy)

Ernst F. Soderlund (Sweden)

Ex-officio Members of Board of Trustees

The Officers of the Association The Editor of THE JOURNAL Past Presidents:

Shepard B. Clough

Withiam N. Parkzer

Ralph W. Hidy 